\title{
URGENSI PENAFSIRAN AL-QUR'AN YANG BERCORAK INDONESIA
}

\author{
Achyar Zein \\ Fakultas Tarbiyah IAIN Sumatera Utara \\ Jl. Willem Iskandar Pasar V Medan Estate, Medan, 20371 \\ e-mai: achyar.zein@yahoo.com
}

\begin{abstract}
Abstrak: Al-Qur'an yang bersifat universal diperuntukkan bagi semua manusia, tidak terkecuali bangsa Indonesia. Penafsiran terhadap al-Qur'an tentu tidak dilepaskan dari konteks sosial masyarakat yang bersangkutan. Karena itu, penafsiran al-Qur'an yang bercorak keindonesiaan merupakan sebuah keniscayaan. Dalam artikel ini, penulis memperlihatkan urgensi penafsiran al-Qur'an yang bercorak keindonesiaan, mengingat penafsiran yang ada seperti yang diwakili oleh Mahmud Yunus, T.M. Hasbi As-Shiddieqy, HAMKA dan M. Quraish Shihab, masih lebih banyak corak kearabannya. Setidaknya, hal ini menjadi simbol kontinuitas dari upaya kajian fikih yang sudah lebih menunjukkan corak keindonesiaan.
\end{abstract}

\begin{abstract}
The Importance of Qur'anic Interpretation in Indonesian Form. Al-Qur'an with its universal character is provided for all human kind, and Indonesian people are not an exception. The interpretation of the Qur'an cannot be separated from its respective social context, and as such Qur'anic interpretation in the Indonesian form is a necessity. In this article, the author attempts to explain the need of interpreting the Qur'an in line with the Indonesian context, considering such interpretations available thus far as those of Mahmud Yunus, T.M. Hasbi AsShiddieqy, HAMKA and M. Quraish Shihab are greatly featured in Arabic circumstances. Nontheles, these works have become a symbol of continuity of Islamic legal studies effort that have demonstrated Indonesianized characteristic of Islam.
\end{abstract}

Kata Kunci: penafsiran, corak, Indonesia

\section{Pendahuluan}

Ketika al-Qur'an menyatakan bahwa kehadirannya sebagai petunjuk bagi manusia, tanpa membatasinya kepada etnis dan generasi tertentu, maka secara otomatis setiap ayatayatnya tidak pernah berhenti kepada satu makna. Pernyataan ini terungkap pada kalimat ( ) yang artinya "petunjuk bagi sekalian manusia" yang menurut al-Râzî (w. 606 H), petunjuk bagi siapa saja untuk menuju kebenaran. Karena, ayat-ayat al-Qur’an menjelaskan 
dan menjabarkan cara-cara untuk menuju kebenaran dan memisahkan antara yang hak dan yang batil. ${ }^{1}$

Selain itu, al-Qur'an juga menggunakan kalimat seruan yang bersifat universal seperti ( ) yang artinya "wahai sekalian manusia." Menurut al-Samarqandî (w. 375 H), sasaran ayat ini bersifat umum (sekalian manusia) walaupun kadang-kadang penggunaan kalimat ( ) ini khusus ditujukan kepada orang-orang Makkah namun pesan yang terkandung di dalamnya tetap saja berlaku umum kepada sekalian manusia. ${ }^{2}$

Jika al-Qur'an berbicara kepada manusia secara totalitas maka isyarat yang dapat ditangkap adalah bahwa makna ayat-ayat al-Qur'an tidak pernah terbatas kepada ruang dan waktu tertentu. Karena itu, penafsiran terhadap ayat-ayat al-Qur'an yang sesuai dengan kepribadian etnis dan generasi tertentu perlu dilakukan supaya petunjuknya dapat direalisasikan.

Sebagai contoh, ketika al-Qur'an memerintahkan untuk mengambil zakat dari sebagian harta mereka (orang-orang kaya) maka al-Qur'an tidak membuat batasan mengenai jenisjenis harta yang akan diambil. ${ }^{3}$ Dengan demikian, yang dikatakan harta tidak terbatas kepada pemahaman suatu komunitas tertentu, karena boleh jadi orang-orang terdahulu tidak menganggapnya sebagai harta karena tidak memiliki nilai jual, berbeda halnya dengan orang-orang yang hidup belakangan.

Ketika ayat perintah untuk mengambil zakat ini turun, Rasulullah tidak mewajibkan zakat pada rumah karena tidak memiliki nilai jual karena masyarakat pada zaman Rasulullah adalah masyarakat yang nomaden (berpindah-pindah). Perbuatan Rasulullah ini tidak dapat dipahami sebagai satu-satunya tafsir terhadap ayat dimaksud yang berlaku untuk selamanya, tetapi hanya sebagai batasan yang disesuaikan dengan kondisi pada masa itu. Jika perbuatan Rasulullah dipahami sebagai satu-satunya tafsir terhadap ayat dimaksud, maka harta kekayaan yang diinvestasikan kepada rumah tidak akan pernah tersentuh oleh zakat. Dengan demikian, keumuman ayat-ayat al-Qur'an yang seyogianya tidak terikat kepada ruang dan waktu menjadi terbatas oleh pandangan komunitas tertentu.

Berdasarkan hal ini maka ayat-ayat al-Qur'an yang berbicara pada tataran global sudah seharusnya diinterpretasikan sesuai dengan kepribadian suatu masyarakat. Dengan kata lain, makna-makna yang tekandung di dalam suatu ayat tidak akan pernah berhenti kepada generasi tertentu, tetapi masih terbuka peluang untuk mencari makna yang lain untuk generasi yang lain terlebih lagi jika al-Qur'an sendiri tidak memberikan batasan-batasan.

${ }^{1}$ Al-Imâm al-Fakhr al-Dîn al-Râzî, Mafâtîh al-Ghayb, Juz V, Cet. 3 (Bayrût: Dâr al-Ihyầ' alTurâts al-'Arabî, t.t.), h. 87.

${ }^{2}$ Abû al-Layts Nashr bin Muhammad bin Aḥmad al-Samarqandî, Bah̆r al-'Ulûm, Juz I (alMaktabah al-Syâmilah, http:// www. altafsir.com, al-Ishdâr al-Tsânî), h. 26.

${ }^{3}$ Lihat, Q.S. al-Taubah/9: 103. 


\section{Kontinuitas Petunjuk al-Qur'an}

Antusias para mufasir untuk menggali kandungan makna-makna al-Qur'an (madhmûn ma'âni al-Qur'ân)-yang diyakini cukup relevan untuk menjawab berbagai aspek kehidupan berimplikasi kepada lahirnya berbagai metodologi tafsir. Metodologi ini dibangun berdasarkan asumsi bahwa kandungan makna-makna al-Qur'an memiliki hubungan yang signifikan dengan perkembangan kehidupan manusia. Adanya hubungan yang signifikan ini memberi dorongan bagi para mufasir untuk mencari kandungan makna-makna dimaksud dengan bertitik tolak dari sebuah keyakinan bahwa al-Qur'an adalah sumber petunjuk.

Konsekwensi menjadikan al-Qur'an sebagai sumber petunjuk atau sumber inspirasi akan membawa kepada suatu pemahaman bahwa makna-makna yang terkandung di dalam ayat-ayat al-Qur'an tidak pernah berhenti kepada satu penafsiran. Karena itu, diperlukan penafsiran-penafsiran baru atau memakai penafsiran lama yang masih relevan supaya petunjukpetunjuk al-Qur'an dapat dipahami di setiap masa dan tempat.

Urgensi melakukan penafsiran baru terhadap ayat-ayat al-Qur'an dapat diinspirasi melalui salah satu ciri khasnya yang fleksibel. Ciri khas ini menjadikan al-Qur'an bagaikan sebuah wadah yang siap menampung segala bentuk pemaknaan terhadapnya. Sekalipun pola penafsiran terhadap ayat-ayat al-Qur'an terus saja mengalami penambahan bahkan perubahan namun sama sekali tidak mengurangi esensi dan eksistensi al-Qur'an sebagai wahyu Tuhan. Justeru itu, penafsiran dengan metode apapun yang digunakan semakin menambah khazanah dan kekayaan makna-makna dari ayat-ayat al-Qur'an itu sendiri.

Berdasarkan hal ini, kemunculan term aliran modern dalam Islam sama sekali tidak pada tempatnya untuk dipertentangkan dengan pesan-pesan al-Qur'an. Semangat aliran modern ini adalah untuk menggali pesan-pesan al-Qur'an dengan alasan bahwa pesan-pesannya tetap relevan dengan perkembangan sosio-kultural manusia. Karena itu, term yang seperti ini harus dipandang secara objektif dengan melihat kontribusi yang disumbangkannya untuk menggali khazanah petunjuk di dalam al-Qur'an.

Embrio munculnya aliran modern dalam Islam ini sudah dimulai pada masa kehidupan Ibn Taymiyyah (abad 13 dan 14). Pada masa ini Ibn Taymiyyah sudah mulai melakukan peninjauan ulang terhadap kajian-kajian keagamaan yang dilakukan oleh para pendahulunya. Melalui tinjauan ulang ini maka pemikiran-pemikiran yang dikemukakan oleh Ibn Taymiyyah banyak yang berbeda bila dibanding dengan pemikiran-pemikiran para pendahulunya. ${ }^{4}$

Pada prinsipnya, al-Qur’an juga turun membawa pesan-pesan pembaharuan dan karena itu semangat pesan al-Qur'an ini harus ditangkap supaya dapat dijewantahkan dalam kehidupan sehari-hari. Bertitik tolak dari pengalaman sejarah, maka pada masa sahabat telah terjadi kemajuan pemikiran dimana mereka memahami ayat-ayat al-Qur'an dengan

${ }^{4}$ Lihat H.A.R. Gibb, Modern Trends in Islam, terj. Machnun Husein, Aliran-aliran Modern dalam Islam (Jakarta: Rajawali, 1990), h. xvii. 


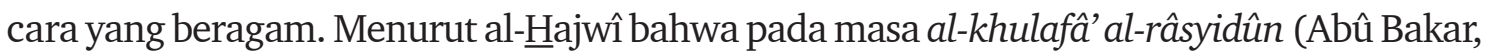
'Umar, 'Utsman dan 'Ali) adalah masa pengembangan pemikiran karena para sahabat langsung melihat ayat-ayat al-Qur'an sebagai sumber dan memberikan berbagai penafsiran. ${ }^{5}$

Kemajuan pemikiran pada masa khalifah yang empat ini disebabkan kejelian mereka memanfaatkan momen terbukanya 'kran' ijtihad yang dapat memotivasi kebebasan berpikir mereka serta munculnya kasus-kasus yang belum ada format sebelumnya. Dengan demikian, hasil ijtihad yang mereka lakukan dalam menafsirkan ayat-ayat al-Qur'an sangat layak dijadikan sebagai referensi bagi generasi berikutnya. Justru itu peran aktif ijtihad pasca sahabat diyakini tidak akan jauh terpisah dari bingkai ijtihad sahabat sebelumnya.

Memposisikan al-Qur'an sebagai petunjuk berarti harus ada upaya yang dilakukan secara terus-menerus untuk menggali makna-makna yang terkandung di dalamnya dan tidak hanya mencukupkan makna-makna yang sudah dicetuskan oleh para pendahulu. Untuk mendapatkan penambahan dan peralihan makna-makna ini, maka kondisi sosial sudah seharusnya dipertimbangkan dalam memahami ayat-ayat al-Qur'an. Kondisi sosial inilah yang digunakan Nabi Muhammad SAW. ketika memberikan pemahaman terhadap ayatayat al-Qur'an kepada masyarakat sehingga al-Qur'an dapat mereka jadikan sebagai solusi alternatif terhadap problema-problema yang berkaitan dengan kehidupan mereka ketika itu.

Sebagai solusi alternatif, maka ayat-ayat al-Qur'an selalu berbicara pada tataran universal yang tingkat akurasinya dapat diinterpretasi dalam konteks lokal agar ayat-ayat al-Qur'an terkesan lebih dinamis, cocok dan sesuai kapan dan dimana saja. Berdasarkan hal ini, maka pengkajian terhadap ayat-ayat al-Qur'an terus saja berlanjut karena kandungan makna ( ) yang terdapat di dalam al-Qur'an memiliki cakupan yang sangat luas.

Isyarat tentang keluasan makna ini disebutkan juga di dalam al-Qur'an yang sekiranya lautan dijadikan tinta dan pohon-pohon dijadikan pena niscaya tidak akan habis-habisnya (dituliskan) kalimat Allah, sebagaimana disebutkan pada ayat-ayat berikut:

Selain ayat ini masih ada lagi ayat lain yang pernyataannya hampir sama yaitu sebagai berikut:

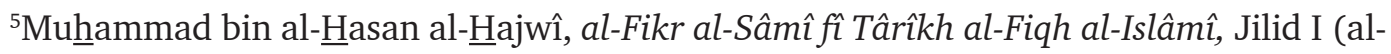
Madînah al-Munawwarah: al-Maktabah al-'Ilmiyah, 1396 H), h. 227-228.

${ }^{6}$ Q.S. al-Kahfi/18: 109. Arti ayat ini adalah sebagai berikut "Katakanlah, sekiranya lautan menjadi tinta untuk (menulis) kalimat-kalimat Tuhanku, sungguh habislah lautan itu sebelum habis (ditulis) kalimat-kalimat Tuhanku, meskipun Kami datangkan tambahan sebanyak itu pula."

${ }^{7}$ Q.S. Luqmân/31: 27. Arti ayat dimaksud adalah sebagai berikut "Dan seandainya pohon- 
Kedua ayat ini mengisyaratkan bahwa ayat-ayat al-Qur'an adalah multimakna dan karenanya manusia hanya tinggal mencari makna yang sesuai dengan kulturnya. Isyarat ayat ini menurut al-Tsa'alabî (w. 876 H) menunjukkan bahwa al-Qur'an adalah lautan penelitian dan pemikiran. Dengan demikian, Allah telah memberikan cahaya ke dalam hati seorang Muslim masing-masing dengan menjadikannya sebagai petunjuk. ${ }^{8}$ Pernyataan ayat ini juga dapat dipahami sebagai pernyataan tentang luasnya ilmu Allah dan sifat-Nya yang mutakallim sehingga setiap perkataan-Nya sesuai di segala situasi dan kondisi. ${ }^{9}$

Menurut Ibn Katsîr (w. 774 H), ayat ini menceritakan tentang kebesaran, keagungan dan kemuliaan Tuhan, nama-nama-Nya yang baik dan sifat-sifat-Nya yang tinggi. Demikian juga halnya dengan kalimat-kalimat-Nya yang sempurna yang tidak dapat dikuasai seorang pun sehingga tidak ada seorang manusia yang mampu mengkaji hakikat dan menghitungnya. ${ }^{10}$

Keluasan makna inilah yang menempatkan al-Qur'an sebagai kitab petunjuk sehingga setiap generasi sah-sah saja memberikan penafsiran yang berbeda dengan penafsiran sebelumnya sesuai dengan sosio-kultural kehidupan masing-masing. Karena itu, jika ayat-ayat al-Qur'an dipahami hanya memiliki satu makna berarti sudah terjadi pengklaiman terhadap otoritas Tuhan yang memiliki hak paten terhadap makna yang sebenarnya. Bila hal ini terjadi, maka kehadiran al-Qur'an sebagai kitab petunjuk patut dipertanyakan karena penafsiran orangorang terdahulu terhadap ayat-ayat al-Qur'an boleh jadi tidak relevan lagi dalam konteks kekinian.

Khaled M. Abou el-Fadl-sebagaimana yang digambarkan oleh M. Amin Abdullahtelah menunjukkan kecemasannya tentang adanya upaya pihak reader (pembaca) yang melangkahi atau ingin menyamai wewenang author (pengarang). Kecemasan Abou elFadl ini disebabkan adanya klaim dari pihak reader yang memberikan pengertian tunggal terhadap teks yang dalam hal ini adalah al-Qur'an yang seolah-olah maknanya hanya satu. Menurutnya, sekiranya hal ini terjadi maka tindakan tersebut dapat dinyatakan sebagai bentuk despotisme dan sekaligus sebagai bentuk penyelewengan (corruption). ${ }^{11}$

Esensi dan eksistensi al-Qur'an, selain sebagai sumber petunjuk maka al-Qur'an juga adalah sumber utama dan pertama dalam ajaran Islam yang diyakini tetap sesuai dengan

pohon di bumi menjadi pena dan laut (menjadi tinta), ditambahkan kepadanya tujuh laut (lagi) sesudah (kering)nya, niscaya tidak akan habis-habisnya (dituliskan) kalimat Allah, sesungguhnya Allah Maha Perkasa lagi Maha Bijaksana."

${ }^{8}$ Abû Zayd 'Abd al-Rahmân bin Muhammad bin Makhlûf al-Tsa'âlabî, al-Jawâhir alfì Tafsîr al-Qur'ân, Juz III (al-Maktabah al-Syâmilah, http://www.altafsir. com, al-Ishdâr alTsânî), h. 199.

${ }^{9}$ Abû Bakr Jâbir al-Jazâ'irî, Aysar al-Tafâsîr, Juz III (al-Maktabah al-Syâmilah, http:// www. altafsir.com, al-Ishdâr al-Tsânî), h. 255.

${ }^{10} I$ Ibn Katsîr, Tafsîr al-Qur'ân al-Azhîm, Juz VI (al-Maktabah al-Syâmilah, www.quran complex.com, al-Ishdâr al-Tsânî), h. 348.

${ }^{11}$ Selengkapnya lihat, Khaled M. Abou el-Fadl, Atas Nama Tuhan: dari Fikih Otoriter ke Fikih Otoritatif, terj. R. Cecep Lukman Yasin (Jakarta: Serambi Ilmu Semesta, 2004), h. xi. 
perkembangan zaman. Pernyataan yang menyebut bahwa ayat-ayat al-Qur'an (

) yang artinya "cocok di segala situasi dan kondisi" menunjukkan bahwa penafsiran terhadap ayat-ayat al-Qur'an tidak pernah berhenti pada suatu masa, tempat dan generasi.

Mengingat bahwa luasnya cakupan makna yang dapat digali dari ayat-ayat al-Qur'an, maka perangkat-perangkat keilmuwan kontemporer seperti bidang sosiologi dan antropologi patut dijadikan sebagai "alat bantu" untuk memahami keluasan makna-makna dari ayatayat al-Qur'an. Dalam tataran ini, diperlukan sifat selektifitas dalam menggunakan perangkatperangkat klasik karena dikhawatirkan bahwa perangkat-perangkat dimaksud dapat membatasi keluasan makna ayat-ayat al-Qur'an. Pembatasan makna ini akan berimplikasi kepada esensi dan eksistensi al-Qur'an yang kemungkinan pemaknaan terhadap suatu ayat dapat menjadi petunjuk pada suatu masa, tapi tidak pada masa-masa berikutnya. Karena itu, penggunaan perangkat sabab al-nuzûl harus dipahami sebagai "alat bantu" untuk memahami ayat-ayat bukan untuk mencari makna satu-satunya.

Ungkapan bahwa "yang dilihat dari al-Qur'an adalah lafaznya yang umum bukan sebab yang khusus" (

) pada dasarnya mengindikasikan bahwa pesan-pesan al-Qur'an tetap sejalan dengan perubahan sosial. Di sinilah letak pentingnya mendudukkan posisi al-Qur'an sebagai kitab petunjuk yang kehadirannya dapat dijadikan kontribusi oleh semua pihak. Karena itu, ayat-ayat al-Qur'an pada prinsipnya adalah acuan pada tataran filosofis, bukan pada tataran praktis. Ketika al-Qur'an menyatakan bahwa hukuman bagi seorang pembunuh adalah dibunuh (qishâsh), maka yang seharusnya menjadi kajian adalah kriteria dari suatu pembunuhan, bukan alat yang digunakan untuk membunuh. Melalui kriteria ini, maka perbuatan-perbuatan lain yang berindikasi kepada pembunuhan dalam kehidupan modern ini dapat dimasukkan ke dalam kriteria yang terdapat dalam ayat.

Bila al-Qur'an dipahami sebagai acuan pada tataran filosofis, maka petunjuk-petunjuk al-Qur'an dimaksud tidak mesti diterjemahkan dalam format yang kaku, karena al-Qur'an tidak pernah menetapkan hukum dalam format tertentu dan begitu juga cara pelaksanaannya. Adapun yang ditetapkan al-Qur'an adalah prinsip-prinsip dasar untuk mewujudkan kemaslahatan manusia. Kemaslahatan dimaksud tidak mesti mengacu kepada satu format tertentu karena lingkungan, masa dan situasi yang manusia hidup di dalamnya senantiasa mengalami perubahan. Karena itu, suatu hukum dapat mewujudkan kemaslahatan pada waktu tertentu, akan tetapi belum tentu dapat diwujudkan pada waktu yang lain. ${ }^{12}$

Petunjuk ini diuraikan dalam bentuk aturan-aturan yang kadang-kadang dilakukan melalui perintah dan larangan. Konsekwensi dari aturan-aturan ini dapat ditandai dengan penghargaan bagi yang mentaatinya dan hukuman bagi yang melanggarnya. Para ulama sepakat menempatkan al-Qur'an pada posisi pertama dalam menetapkan hukum, meskipun

12‘Afîf 'Abd al-Fattâh Thabbârah, Rûh al-Dîn al-Islâmî, Cet. 26 (Bayrût: Dâr al-'Ilm li alMalâyîn, 1985), h. 290. 
al-Qur'an sendiri tidak pernah menyatakan hal ini secara tegas. Kesepakatan ini dilandasi melalui pernyataan al-Qur'an bahwa dirinya sebagai kitab petunjuk bagi semua umat manusia. ${ }^{13}$

Menurut catatan 'Abd al-Wahhâb Khallâf bahwa penafsiran yang beragam terhadap ayat-ayat al-Qur'an sudah pernah dilakukan pada masa sahabat khususnya ketika menafsirkan nash-nash hukum dalam al-Qur'an dan al-Sunnah. Interpretasi sahabat yang beragam ini, menurut Khallâf, dapat dijadikan sebagai referensi hukum dan begitu juga hasil fatwa-fatwa mereka yang tidak ada ketentuannya dalam nash dapat dianggap sebagai dasar ijtihad dan istinbâth. ${ }^{14}$

Adapun sumber tasyrî́pada fase ini menurut Shubhî al-Mahmmashânî adalah al-Qur'an dan al-sunnah, kemudian ijtihad (bilamana tidak terdapat informasi dari kedua sumber ini). Metode yang mereka tempuh ialah berpegang kepada ma'qûl al-nash (yaitu 'illat yang dimaksudkan oleh Syâri' dalam hukum syariat yang kadang-kadang bisa saja berbeda dengan zhahir nash). Mereka juga menggunakan qiyâs dengan melihat hikmah dan 'illat. Adapun keputusan yang tidak ada nash, maka para sahabat ini mengambil jalan musyawarah yang disebut dengan $\ddot{j m} \hat{a}^{6}{ }^{6}{ }^{15}$

Terinspirasi dari perbuatan sahabat ini, maka term-term yang selama ini sudah dianggap baku oleh sebagian orang dicoba ditafsirkan ulang (reinterpretasi) karena term-term yang lama sudah tidak sesuai lagi dengan keberadaan masyarakat sekarang. Sebagai contoh, ulama dahulu memahami bahwa yang dimaksud dengan pencuri dalam ayat al-Qur'an adalah "seseorang yang mengambil harta orang lain secara sembunyi-sembunyi". ${ }^{16}$ Penafsiran ini tentu saja masih relevan dalam dunia modern, namun tidak harus terhenti kepada satu makna, karena pencuri dalam dunia modern sekarang tidak hanya terbatas kepada harta, tetapi merambah ke format-format yang lain dengan modus yang berbeda-beda pula.

Kelompok yang merasa kurang puas dengan penafsiran tunggal ini akhirnya berusaha menggali pesan-pesan al-Qur'an melalui pendekatan yang berbeda-beda. Bila pada pemikiran

${ }^{13} \mathrm{Al}$-Qur'ân menyatakan dirinya sebagai petunjuk bagi manusia dapat dilihat dalam Q.S. al-Baqarah ayat 185 dan Q.S. Âli 'Imrân ayat 4. Selain itu al-Qur'ân juga menjadi petunjuk bagi orang-orang yang takwa sebagaimana informasi Q.S. al-Baqarah ayat 2, Q.S. Âli 'Imrân 138 dan Q.S. al-Mâ'idah ayat 46, petunjuk bagi sekalian alam sebagaimana tertera dalam Q.S. Âli 'Imrân ayat 96, petunjuk bagi orang-orang yang beriman lihat Q.S. al-A'râf ayat 203, Q.S. Yûnus ayat 57, Q.S. Yûsuf ayat 111, Q.S. al-Nahl ayat 64 dan 89, Q.S. al-Naml ayat 2 dan 77, Q.S. Fushshilat ayat 44, petunjuk bagi orang-orang Muslim sebagaimana terdapat dalam Q.S. al-Nahl ayat 16, petunjuk bagi orang-orang yang Muhsin terdapat dalam Q.S. Luqmân ayat 3, petunjuk bagi Ûlî al-Âlbâb sebagaimana terdapat dalam Q.S. al-Mu'min ayat 54 dan petunjuk bagi kaum yang yakin terdapat dalam Q.S. al-Jâtsiyah ayat 20.

${ }^{14 ‘} \mathrm{Abd}$ al-Wahhâb Khallâf, Khulâshah Târîkh al-Tasyrî‘ al-Islâmî, Cet. 8 (Jakarta: al-Majlis al-A'la al-Indûnîsî li al-Da'wah al-Islâmiyah, 1968), h. 30.

${ }^{15}$ Shubhî al-Mahmashânî, al-Awdhâ' al-Tasyrî́iyah fí al-Duwal al-Arabiyah Mâdhîyuhâ wa Hâdhiruhâ, Cet. 4 (Bayrût: Dâr al-'Ilm li al-Malâyîn, 1981), h. 98.

${ }^{16}$ Muhammad 'Alî al-Shâbûnî, Rawâ'i‘ al-Bayan Tafsîr Âyât al-Ahkâm min al-Qur'ân, Juz I, h. 553. 
klasik mendekati ayat-ayat al-Qur'an hanya melalui satu metode saja, maka pemikiran modern akan mendekatinya melalui berbagai aspek seperti kebudayaan dan teknologi. Kemudian kelompok ini juga tidak menutup diri dari teori-teori dan metode-metode yang diketemukan oleh orang-orang yang non Muslim dan bahkan penemuan mereka ini dianggap sebagai kontribusi dalam memahami ayat-ayat al-Qur'an.

Ketidakpuasan sebagian orang kepada penafsiran tunggal terhadap ayat-ayat al-Qur'an menyebabkan muncul upaya-upaya reinterpretasi. Kemunculan pemikiran ini disebabkan bahwa penafsiran tunggal terhadap pesan-pesan al-Qur'an tidak membumi dalam kehidupan masyarakat karena perubahan sosio kultural sudah semakin jauh. Beranjak dari ketidakpuasan inilah, maka muncul pemikiran untuk menafsirkan kembali ayat-ayat al-Qur'an yang sesuai dengan konteks budaya atau (kalau di Indonesia) yang bercorak Indonesia agar posisi al-Qur'an sebagai kitab petunjuk benar-benar membumi dalam kehidupan.

\section{Penafsiran yang Bercorak Indonesia}

Adapun dimaksud dengan penafsiran yang bercorak Indonesia ialah menafsirkan ayat-ayat al-Qur'an yang bersifat global sesuai dengan konteks keindonesiaan. Pada umumnya, penafsiran seseorang terhadap ayat-ayat al-Qur'an tidak terlepas dari konteks sosio kultural (budaya masyarakat) dimana mufasir bersangkutan hidup.

Menurut Islah Gusmian, dalam bukunya Khazanah Tafsir Indonesia, bahwa ada dua karya tafsir yang dengan tegas mempertimbangkan aspek kontekstualitas dimana penafsir berada dan hidup yaitu Tafsir Tematik al-Qur'an tentang Hubungan Sosial Antarumat Beragama dan Dalam Cahaya al-Qur'an. Menurutnya, pengarang tafsir ini Syu'bah, selalu berangkat dari problem kontekstual dan terkini yang terjadi di Indonesia. Tema-tema yang dikaji pun bersifat spesifik keindonesiaan. ${ }^{17}$

Karenaitu, penafsiran terhadap ayat-ayatal-Qur'an belum memadaijika hanya menggunakan penafsiran orang lain dimana budaya dan pola kehidupannya berbeda, terlebih lagi jika interval waktunya terlalu jauh. Dalam tataran ini, diperlukan penafsiran ayat-ayat al-Qur'an yang bercorak Indonesia supaya tidak muncul kesan bahwa makna ayat-ayat al-Qur'an hanya cocok dikonsumsi pada waktu dan tempat tertentu. ${ }^{18}$

${ }^{17}$ Islah Gusmian, Khazanah Tafsir Indonesia dari Hermeneutika hingga Ideologi (Jakarta: Teraju, 2003), h. 272.

${ }^{18}$ Upaya-upaya untuk menafsirkan al-Qur'ân telah dilakukan oleh para intelektual Muslim di Indonesia baik bersifat bagian-bagian tertentu atau menafsirkan seluruh ayat-ayat al-Qur'ân. Howard M. Federspiel telah melakukan penelitian tentang karya-karya para intelektual Muslim Indonesia yang berkaitan dengan al-Qur'ân yang diberi judul Popular Indonesian Literature of the Qur'an. Hasil penelitian ini diterjemahkan oleh Tajul Arifin dalam sebuah buku yang diberi judul Kajian al-Qur'an di Indonesia: Dari Mahmud Yunus Hingga Quraish Shihab. Penelitian Federspiel ini hanya mengungkap sisi tentang pengkajian al-Qur'ân yang dilakukan di Indonesia dan sama sekali tidak mengungkapkan adanya unsur-unsur kepribadian Indonesia di dalam penafsiran. 
Urgensi melakukan penafsiran yang bercorak Indonesia karena ayat-ayat al-Qur'an selalu berbicara dalam konteks umum. Menurut M. Quraish Shihab, penafsiran terhadap al-Qur'an terdiri dari enam corak yaitu sastra bahasa, filsafat dan teologi, penafsiran ilmiah, fikih, tasawuf dan kemudian corak sastra budaya kemasyarakatan yang dimulai oleh Syaikh Muhammad 'Abduh (1849-1905 M). Corak yang terakhir ini berusaha untuk menjelaskan petunjuk ayat-ayat al-Qur'an yang berkaitan langsung dengan kehidupan masyarakat. Dengan kata lain, menjadikan ayat-ayat al-Qur'an untuk menanggulangi fenomena-fenomena yang terjadi di dalam kehidupan masyarakat. ${ }^{19}$

Tanpa ada upaya untuk mengembalikan pesan-pesan al-Qur'an ke dalam budaya lokal, maka petunjuk al-Qur'an sulit terbumikan di dalam kehidupan. Inilah dugaan sementara tentang banyaknya praktik-praktik ibadah yang muncul di masyarakat yang nota benenya tidak punya kerangka acuan di dalam al-Qurân. Demikian juga halnya dengan kemunduran zakat karena ketidakberanian melakukan penafsiran yang bercorak Indonesia sehingga jenis-jenis harta yang dizakati selalu mengacu kepada kehidupan orang Arab.

Fenomena yang seperti ini sudah pernah dikemukakan oleh Hasbi As-Shiddieqy tentang kegundahannya melihat kondisi fikih di Indonesia. Menurutnya, bahwa hukum fikih yang dianut oleh masyarakat Islam Indonesia banyak yang tidak sesuai dengan kepribadian bangsa Indonesia. Mereka cenderung memaksakan keberlakuan fikih imam-imam mazhab. Menurutnya, umat Islam harus dapat menciptakan hukum fikih yang sesuai dengan latar belakang sosiokultural dan religi masyarakat Indonesia. ${ }^{20}$

Meminjam pernyataan Hasbi di atas maka aturan-aturan yang terdapat di dalam al-Qur'an sudah pasti memperhatikan perkembangan peradaban manusia. Karena itu, aturan-aturan dimaksud tidak hanya terbatas kepada komponen masyarakat tertentu demikian juga waktu dan generasi. Untuk menyahuti hal ini, maka penafsiran terhadap ayat-ayat al-Qur'an tidak boleh terhenti kepada interpretasi tunggal.

Ketika Nabi Muhammad menafsirkan ayat tentang kewajiban zakat dan menunjuk harta-harta yang wajib dizakati tentu saja harta dimaksud sesuai dengan keberadaan masyarakat setempat. Perbuatan Nabi ini bukan merupakan penafsiran tunggal, tetapi sebagai metodologi dalam menafsirkan ayat-ayat al-Qur'an yang disesuaikan dengan perkembangan kehidupan dan peradaban masyarakat ketika itu.

Perbuatan Nabi ini menunjukkan bahwa penafsiran terhadap ayat-ayat al-Qur'an harus dilakukan dengan membawa segala atribut-atribut yang ada untuk dijadikan alat bantu dalam memahami keumuman ayat-ayat al-Qur'an. Jika penafsiran Nabi ini dipandang

${ }^{19}$ M. Quraish Shihab, Membumikan al-Qur'an: Fungsi dan Peran Wahyu dalam Kehidupan Masyarakat, Cet. 27 (Bandung: Mizan, 2004), h. 72-73.

${ }^{20}$ Teungku Muhammad Hasbi ash-Shiddieqy, Tafsir al-Qur'anul Majid an-Nuur, Juz I, Cet. 2 (Semarang: Pustaka Rizki Utama, 2000), h. xviii. 
sebagai satu-satunya tafsir, berarti pesan-pesan al-Qur'an hanya dirasakan oleh kelompok tertentu dan tidak untuk kelompok lain.

Al-Qur'an hadir dalam sebuah masa dan ruang. Al-Qur'an turun di Makkah dan Madinah. Al-Qur'an hadir dalam konteks memanusiakan manusia. Begitu pula tafsir al-Qur'an senantiasa dihadirkan agar al-Qur'an mempunyai relevansi dengan zamannya. Nalar yang seperti ini akan memudahkan untuk meyakinkan betapa pentingnya menghadirkan al-Qur'an tidak semata-mata sebagai wahyu, melainkan sebagai ajaran yang membumi dalam rangka mengubah tatanan masyarakat ke arah yang lebih berkeadaban dan berperadaban. ${ }^{21}$

Bila al-Qur'an diperuntukkan bagi semua manusia, maka setiap pesannya sudah pasti sejalan dengan peradaban manusia secara menyeluruh. Sebaliknya, bila ayat-ayat al-Qur'an hanya dibatasi oleh penafsiran tertentu dengan membawa sosio-kultural pada tempat tertentu pula, maka kehadiran ayat-ayat al-Qur'an tidak akan pernah memberikan kontribusi bagi masyarakat yang ada di tempat lain.

Berdasarkan hal ini, maka tidak ada otoritas tunggal dalam menafsirkan ayat-ayat al-Qur'an terlebih lagi ketika al-Qur'an menyatakan kehadirannya sebagai petunjuk kepada semua manusia tanpa terbatas ruang dan waktu. Pernyataan ini menunjukkan bahwa ayatayat al-Qur'an selalu berbicara pada tataran filosofis. Karena itu, ayat-ayat al-Qur'an lebih tepat dipandang sebagai dalil yang dapat melahirkan berbagai inspirasi dan bukan sebagai sumber.

Menurut Frihtjof Schuon, sebagaimana dikutip oleh Hasani Ahmad Said, bahwa sakralitas atau kesucian sebuah kitab tidak terletak pada level ontologisnya dalam bentuk teks, melainkan pada aspek inspirasinya. Sehingga yang membedakan antara kitab suci (al-Qur'an, Injil, Taurat) dengan karya yang lain berada pada wilayah inspirasinya. ${ }^{22}$

Melalui kenyataan ini, perlu terobosan baru untuk memperkenalkan tafsir yang bercorak Indonesia supaya norma-norma dan adat istiadat yang berlaku di negara ini dapat dijadikan kontribusi dalam penafsiran. Urgensi melakukan terobosan ini disebabkan bahwa bangsa Indonesia adalah bagian dari komunitas umat Islam yang memiliki sosio kultural yang berbeda dengan masyarakat Islam lainnya.

Masyarakat Indonesia adalah masyarakat yang kaya dengan norma-norma, adat istiadat dan kaedah-kaedah yang menuntun masyarakat selama ini. Karena itu, masyarakat Indonesia adalah masyarakat yang sudah lama mengenal norma-norma, adat istiadat dan kaedahkaedah yang bahkan sampai sekarang gaungnya masih terlihat. Kekayaan yang seperti

${ }^{21} Z$ uhairi Misrawi, Al-Qur'an Kitab Toleransi: Tafsir Tematik Islam Rahmatan Lil 'Alamin, (Jakarta: Gramedia Widiasarana Indonesia, 2010), h. 147.

${ }^{22}$ Hasani Ahmad Said, "Metodologi Penafsiran al-Qur'an Kontemporer: Telaah atas Pemikiran Nasr Hamid Abu Zayd dan Mohammed Arkoun," dalam Jurnal Suhuf Kajian Al-Qur'an dan Kebudayaan, Vol. 4. No. 1, 2011 (Lajnah Pentashihan Mushaf al-Qur'an Badan Litbang dan Diklat Kementerian Agama RI), h. 81. 
ini dapat diakomodir sebagai ciri khas penafsiran terhadap ayat-ayat al-Qur'an yang bercorak Indonesia dan sekaligus merupakan cerminan dari kekayaan masyarakat Indonesia itu sendiri.

Urgensi melakukan penafsiran yang bercorak Indonesia ini terungkap dari pernyataan HAMKA di dalam pendahuluan Tafsir al-Azhar, bahwa tafsir ini ditulis dalam suasana baru, di negara yang penduduk Muslimnya lebih besar jumlahnya dari penduduk yang lain, sedang mereka haus akan bimbingan agama haus hendak akan mengetahui rahasia al-Qur'an, maka pertikaian-pertikaian mazhab tidaklah dibawakan dalam tafsir ini, dan tidaklah penulisnya ta'ashshub kepada suatu paham, melainkan mencoba segala upaya mendekati maksud ayat, menguraikan makna dari lafaz bahasa Arab ke dalam bahasa Indonesia dan memberi kesempatan orang buat berpikir. ${ }^{23}$

Sebagai contoh, mulai dari dulu masyarakat Indonesia dikenal sebagai masyarakat hukum meskipun hukum yang berlaku belum terkodifikasi dengan baik. Karena itu, setiap produk hukum yang berasal dari negeri ini tidak semestinya dipertentangkan karena orientasi dari produk hukum ini ialah untuk mengembalikan masyarakat Indonesia ke jati diri semula.

Berdasarkan hal ini pula, ide untuk membuat penafsiran yang bercorak Indonesia sah-sah saja dilakukan, bahkan sudah merupakan kebutuhan yang sangat mendesak. Hal ini perlu dilakukan mengingat perkembangan peradaban di Tanah Air ini sudah semakin maju dan berkembang. Karena itu, yang mengerti tentang kondisi kehidupan bangsa ini adalah orang Indonesia sendiri.

Menurut Amin Abdullah ketika memberikan pengantar untuk buku Khazanah Tafsir Indonesia karya Islah Gusmian, yang menjadi persoalan mendasar dalam kajian tafsir di IAIN adalah menyangkut pokok-pokok materi kajian, metode dan pendekatan yang digunakan dan ke arah mana studi ini dikembangkan. Menurutnya, bahwa kajian kritis atas tafsir Indonesia tidaklah cukup dibangun hanya secara vertikal historis yang bersifat linier dengan menunjuk pada tahun, sosok penafsir dan tema-tema yang diangkat. Lebih dari itu, kajian yang bersifat horizontal-hermeneutis dengan mengungkap keterpengaruhan-keterpengaruhan yang terjadi, baik dari segi metodologi maupun episteme sosial yang dibangun di dalamnya, merupakan suatu langkah signifikan dalam studi-studi yang bersifat sosio-historis. ${ }^{24}$

Pada prinsipnya, penafsiran yang bercorak Indonesia ini dapat ditangkap melalui pernyataan al-Qur'an yang artinya "taatilah Allah dan taatilah Rasul dan pemimpin-pemimpin kamu." ${ }^{25}$ Kata "pemimpin" di dalam ayat ini adalah pemimpin sendiri yaitu sosok yang dipilih dan yang ditunjuk dan tidak mungkin pemimpin-pemimpin dari negara lain.

${ }^{23}$ Hamka, Tafsir al-Azhar, Juz I (Jakarta: Panjimas, 2004), h. 54. Meskipun HAMKA menyebut bahwa tafsirnya memiliki nuansa baru namun di dalam penafsirannya belum kelihatan konteks keindonesiaan bahkan HAMKA lebih banyak bercerita di luar konteks keindonesiaan.

${ }^{24}$ Amin Abdullah, "Arah Baru Metode Penelitian Tafsir di Indonesia," dalam Khazanah Tafsir Indonesia dari Hermeneutika hingga Ideologi (Jakarta: Teraju, 2003), h. 24.

${ }^{25}$ Lihat, Q.S. al-Nisâ'/4: 59. 
Pada prinsipnya, ayat-ayat al-Qur'an senantiasa berbicara pada tataran filosofis. Hal ini mengindikasikan bahwa pesan dari ayat-ayat dimaksud seharusnya dapat teraplikasi sesuai dengan perkembangan peradaban manusia. Berdasarkan hal ini maka ide untuk memperkenalkan tafsir yang Bercorak Indonesia sudah merupakan tuntutan yang mendesak karena pemahaman tentang tunjukan ayat-ayat al-Qur'an yang berlaku di Tanah Air selama ini masih mengadopsi penafsiran-penafsiran yang datang dari luar.

Padahal, aturan-aturan yang berlaku di negara manapun pada prinsipnya selalu menggali norma-norma, kaedah-kaedah dan nilai-nilai yang terkandung dalam kehidupan manusia (masyarakat yang menjadi sasaran peraturan) demikian juga halnya aturan-aturan yang terdapat dalam ayat-ayat al-Qur'an. Aturan-aturan dalam al-Qur'an ini sekalipun datangnya dari Tuhan namun diyakini tetap memperhatikan perkembangan peradaban manusia karena aturan-aturan tersebut tidak hanya terbatas kepada komponen masyarakat tertentu demikian juga waktu dan generasi.

Ketika Nabi Muhammad SAW. menafsirkan ayat-ayat al-Qur'an yang berbicara tentang kewajiban zakat, maka Nabi menunjukkan bahwa harta-harta yang wajib dizakati adalah harta yang sesuai dengan keberadaan masyarakat setempat seperti kurma, emas, gandum, unta, lembu dan kambing. Penafsiran yang dilakukan oleh Nabi ini tidak dapat dipahami sebagai pembatasan tentang harta-harta yang wajib dizakati. Bila dipahami demikian, maka harta-harta yang ada pada masyarakat di belahan bumi yang lain tidak akan pernah tersentuh kewajiban zakat. Dengan demikian, maka posisi al-Qur'an sebagai kitab petunjuk tidak lagi bersifat general, tetapi sudah terbatas kepada satu komunitas saja.

Apa yang dilakukan oleh Nabi ini bukan merupakan penafsiran tunggal yang absolut, tetapi merupakan metodologi dalam menafsirkan ayat-ayat al-Qur'an yang disesuaikan dengan perkembangan kehidupan dan peradaban masyarakat ketika itu. Perbuatan Nabi ini menunjukkan bahwa penafsiran terhadap ayat-ayat al-Qur'an harus dilakukan dengan membawa segala atribut-atribut yang ada sebagai "alat bantu" untuk memahami keumuman ayat-ayat al-Qur'an.

Pada sisi lain, upaya yang dilakukan oleh Nabi ini adalah sebagai isyarat tentang perlunya penafsiran al-Qur'an yang memiliki kepribadian. Jika penafsiran Nabi Muhammad ini dipandang sebagai satu-satunya penafsiran berarti pesan-pesan al-Qur'an hanya dirasakan oleh kelompok tertentu dan tidak untuk kelompok yang lain karena berbedanya kepribadian.

Bila penafsiran terhadap ayat-ayat al-Qur'an dilakukan oleh Nabi dengan membawa kepribadian yang berlaku di tengah-tengah kehidupan masyarakatnya, maka sudah tentu bahwa makna-makna yang terkandung dalam ayat-ayat al-Qur'an sudah pasti sejalan dengan nurani manusia tanpa harus dibatasi oleh interpretasi-interpretasi tertentu. Sebaliknya, bila ayat-ayat al-Qur'an hanya dibatasi oleh penafsiran tertentu dengan membawa sosiokultural suatu tempat maka penafsiran tersebut akan mengebiri perkembangan budaya masyarakat di tempat lain. 
Berdasarkan hal ini maka tidak ada otoritas tunggal dalam menafsirkan ayat-ayat al-Qur'an terlebih lagi ketika al-Qur'an menyatakan kehadirannya sebagai petunjuk kepada semua manusia ( $\quad$ ) tanpa terbatas ruang dan waktu. Pernyataan al-Qur'an ini mengindikasikan bahwa ayat-ayat yang terkandung di dalamnya selalu berbicara pada tataran filosofis. Karena itu, al-Qur'an nampaknya lebih tepat dipandang sebagai dalil dan bukan sebagai sumber dalam tataran yang sebenarnya.

Melalui kenyataan ini, maka diperlukan terobosan-terobosan baru untuk memperkenalkan penafsiran yang bercorak Indonesia supaya norma-norma dan adat istiadat yang berlaku di negara ini dapat dijadikan sebagai kontribusi dalam menafsirkan ayatayat al-Qur'an yang global. Urgensi melakukan terobosan penafsiran yang bercorak Indonesia ini disebabkan bahwa bangsa Indonesia adalah bagian dari komunitas umat Islam yang memiliki sosio kultural yang berbeda dengan masyarakat Islam lainnya.

Esensi dan eksistensi al-Qur'an sebagai dalil, maka seharusnya perbuatan-perbuatan yang terdapat pada suatu masyarakat tertentu dapat dijadikan kajian serius untuk dilegalkan sesuai dengan prinsip hukum Islam yang terkandung dalam al-Qur'an. Dengan kata lain, tugas "suci" seorang ilmuwan pada tataran ini adalah mencarikan dalil-dalil dari setiap perbuatan yang terdapat di suatu masyarakat, bukan langsung mengklaim secara otoriter bahwa perbuatan tersebut bertentangan dengan al-Qur'an. Dalam tataran ini, kepribadian masyarakat Indonesia patut dijadikan sebagai contoh dalam menafsirkan ayat-ayat alQur'an, karena masyarakat Indonesia adalah masyarakat yang majemuk, berbudaya dan memiliki sistem hukum yang selama ini sudah berlaku di masyarakat.

Masyarakat Indonesia adalah masyarakat yang kaya dengan norma-norma, adat istiadat dan kaedah-kaedah yang menuntun masyarakat selama ini yang sampai sekarang gaungnya masih terlihat sampai saat ini. Kekayaan yang seperti ini dapat diakomodir untuk menafsirkan ayat-ayat al-Qur'an yang bercorak Indonesia dan sekaligus merupakan cerminan dari kekayaan masyarakat Indonesia itu sendiri.

Mulai sejak dulu, masyarakat Indonesia dikenal sebagai masyarakat yang taat terhadap aturan-aturan meskipun aturan-aturan yang berlaku belum terkodifikasi. Karena itu, setiap aturan-aturan dan norma-norma yang berasal dari negeri ini tidak semestinya dipertentangkan karena orientasi dari aturan-aturan dan norma-norma ini adalah untuk mengembalikan masyarakat Indonesia ke jati diri semula. Berdasarkan hal ini, maka ide untuk membuat penafsiran terhadap ayat-ayat al-Qur'an yang bercorak Indonesia sah-sah saja dilakukan dan bahkan sudah merupakan kebutuhan yang sangat mendesak mengingat pesatnya perkembangan kebudayaan masyarakat di tanah air ini.

Menurut Mochtar Kusumaatmadja bahwa secara praktek ketentuan-ketentuan yang berlaku di tengah-tengah masyarakat Indonesia sudah dapat dikategorikan mengandung unsur hukum namun sifatnya tidak tertulis. Dalam konteks ini, Mochtar memberikan dua contoh yaitu ketentuan hukum yang mengatur hubungan perdata dan dagang yang sebenarnya sudah berlaku dalam kenyataan kehidupan masyarakat. Begitu juga masalah warisan nasional 
tentang persamaan hak antara pria dan wanita bahkan adanya ketentuan kewajiban anak memelihara orang tuanya, dan harta tidak dibagi habis merupakan ketentuan hukum yang sudah berlaku di masyarakat. ${ }^{26}$

Ketentuan hukum yang mengatur hubungan perdata dan dagang sebenarnya sudah berlaku dalam kenyataan kehidupan masyarakat walaupun tidak ada undang-undang atau hukum tertulis. Asas-asas hukum perdata seperti pacta sunt servanda (perjanjian yang diadakan harus ditaati), bona fides (iktikad baik) dan kebebasan berkontrak sudah cukup dikenal dan dipergunakan. Ketentuan-ketentuan yang seperti ini dapat dijadikan sebagai "alat bantu" dalam menafsirkan ayat al-Qur'an yang berbicara tentang perintah menepati kontrak ( ),${ }^{27}$ dan ayat muamalah yang dilandasi prinsip kerelaan ( $\quad$ ). ${ }^{28}$ Penafsiran terhadap ayat ( $\quad$ ) demikian juga prinsip kerelaan dalam melakukan muamalah ( ) dapat dilakukan sesuai dengan kepribadian yang berlaku di Indonesia. Dengan demikian, asas-asas hukum perdata seperti yang disebutkan di atas masih tetap mengacu kepada aturan-aturan yang tertera di dalam al-Qur'an.

Adanya ketentuan membagi dua terlebih dahulu harta warisan -yang separohnya diberikan kepada isteri yang masih hidup yang dalam istilah Indonesianya disebut harta syarikat atau "gonogini"-sama sekali tidak diatur dalam sistem warisan Islam. Tetapi, konsep ini sangat sesuai dengan kepribadian bangsa Indonesia maka sistem ini terus berlanjut sampai sekarang dan bahkan sunyi dari berbagai protes. Prinsip ini sebenarnya membuktikan bahwa aturan-aturan yang berlaku di tengah-tengah masyarakat dan dianggap masih relevan merupakan salah satu bukti bahwa masyarakat Indonesia masih kuat berpegang kepada ketentuan-ketentuan yang sudah ada. Demikian juga halnya Pancasila karena merupakan cerminan nilai hidup bangsa Indonesia maka diyakini prinsip-prinsip hukum yang terkandung di dalamnya masih layak untuk dipertahankan dan diyakini mampu untuk mengatasi segala problema masyarakat apalagi 'ruh' dari Filsapat Hukum Pancasila tidak ada yang bertentangan dengan keyakinan masyarakat. ${ }^{29}$

Hukum waris nasional (perdata) dengan adanya persamaan hak dan kedudukan antara wanita dan laki-laki dalam hukum nasional, bisa mengatur pembagian warisan antara anak laki-laki dan perempuan atas dasar yang sama. Prinsip kekeluargaan dan kewajiban anak mengurus orang tua dapat diartikan bahwa orang tua yang tinggal (yang masih hidup) mendapat sekurangnya bagian yang sama dengan anak dengan ketentuan bahwa tidak

${ }^{26}$ Lihat Mochtar Kusumaatmadja, Makalah Seminar Tentang Temu Kenal Cita Hukum dan Penerapan Asas-asas Hukum Nasional Departemen Kehakiman RI, dalam Pemantapan Cita Hukum Dan Asas-asas Hukum Nasional di Masa Kini dan Masa Yang Akan Datang (Jakarta, 22-24 Mei 1995), h. 10.

${ }^{27}$ Lihat, Q.S. al-Mâ'idah/5:1.

${ }^{28}$ Lihat, Q.S. al-Nisâ'/4: 29.

${ }^{29}$ Kusumaatmadja, Makalah Seminar, h. 12. 
semua harta dibagi habis selama masih ada orang tua yang tinggal. Secara praktis ini berarti kalau ada rumah, orang tua yang masih hidup masih bisa menempatinya selama masih hidup.

Kultur masyarakat Indonesia sebagaimana disebutkan di atas dapat dijadikan sebagai kontribusi di dalam menafsirkan ayat-ayat al-Qur'an yang bercorak Indonesia. Jika kepribadian yang seperti ini tidak diikutsertakan di dalam menafsirkan ayat-ayat al-Qur'an maka pesanpesan al-Qur'an tidak akan pernah dapat dipahami secara baik.

\section{Penutup}

Ayat-ayat hukum dalam al-Qur'an yang selalu berbicara pada tataran filosofis mengindikasikan bahwa pesan dari ayat-ayat dimaksud seharusnya dapat teraplikasi sesuai dengan perkembangan peradaban manusia. Berdasarkan hal ini maka ide untuk memperkenalkan Tafsiryang Bercorak Indonesia sudah merupakan tuntutan yang mendesak karena hukumhukum yang berlaku di Tanah Air ini masih mengadopsi produk-produk hukum dari luar. Munculnya term "pemikiran modern dalam Islam" sama sekali tidak mengurangi nilainilai petunjuk al-Qur'an dan bahkan esensi dan eksistensinya sama sekali tidak bertentangan dengan ayat-ayat al-Qur'an. Hal ini semakin meyakinkan jika ayat-ayat al-Qur'an memiliki orientasi back to future ( ) yaitu memacu manusia untuk dapat hidup secara modern. Karena itu, pemikiran modern dalam Islam adalah merupakan kontribusi yang tidak ternilai harganya dalam rangka membumikan pesan-pesan al-Qur'an.

\section{Pustaka Acuan}

Abou el-Fadl, Khaled M. Atas Nama Tuhan: Dari Fikih Otoriter ke Fikih Otoritatif, terj. R. Cecep Lukman Yasin (Jakarta: Serambi Ilmu Semesta, 2004).

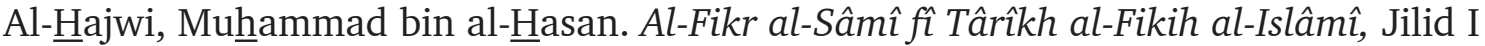
(al-Madînah al-Munawwarah: al-Maktabah al-'Ilmiyah, 1396 H).

Al-Jazâ'irî, Abû Bakr Jâbir. Aysar al-Tafâsîr, Juz III (al-Maktabah al-Syâmilah, http:// www. altafsir.com, al-Ishdâr al-Tsânî).

Al-Mahmashânî, Shubhî. al-Awdhâ'al-Tasyrî́iyah fí al-Duwal al-Arabiyah Mâdhîyuhâ wa Hâdhiruhâ, Cet. 4 (Bayrût: Dâr al-'Ilm li al-Malâyîn, 1981).

Al-Râzî, al-Imâm al-Fakhr al-Dîn, Mafâtîh al-Ghayb, Juz V, Cet. 3 (Bayrût: Dâr al-Ihyâ' al-Turrâts al-'Arabî, t.t.).

Al-Samarqandî, Abû al-Layts Nasr bin Muhammad bin Aḥmad. Bahr ral-'Ulûm, Juz I (alMaktabah al-Syâmilah, http:// www. altafsir.com, al-Ishdâr al-Tsânî).

Al-Shâbûnî, Muhammad 'Alî. Rawâ'i' al-Bayan Tafsîr Âyât al-Ahkkâm min al-Qur'an. Juz I (al-Maktabah al-Syâmilah, http:// www. altafsir.com, al-Ishdâr al-Tsânî).

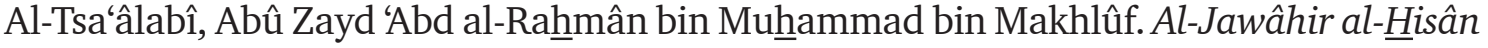


fí Tafsîr al-Qur'an, Juz III (al-Maktabah al-Syâmilah, http:// www.altafsir.com, alIshdâr al-Tsânî).

Gibb, H.A.R. Aliran-aliran Modern dalam Islam, terj. Machnun Husein (Jakarta: Rajawali, 1990).

Hamka. Tafsir al-Azhar, Juz I (Jakarta: Panjimas, 2004).

Hasani Ahmad Said. "Metodologi Penafsiran al-Qur'an Kontemporer: Telaah atas Pemikiran Nasr Hamid Abu Zayd dan Mohammed Arkoun," dalam Jurnal Suhuf Kajian alQur'an dan Kebudayaan, Vol. 4. No. 1, 2011 (Lajnah Pentashihan Mushaf Al-Qur'an Badan Litbang dan Diklat Kementerian Agama RI).

Ibn Katsîr. Tafsîr al-Qur'an al-Azhîm, Juz VI (al-Maktabah al-Syâmilah, www.quran complex.com, al-Ishdâr al-Tsânî).

Islah Gusmian, Khazanah Tafsir Indonesia dari Hermeneutika hingga Ideologi (Jakarta: Teraju, 2003).

Khallâf, 'Abd al-Wahhâb. Khulâshah Târîkh al-Tasyrî‘ al-Islâmî, Cet. 7 (Jakarta: al-Majlis al-A'la al-Indûnîsî li al-Da'wah al-Islâmiyah, 1968).

M. Quraish Shihab. Membumikan Al-Qur'an: Fungsi dan Peran Wahyu Dalam Kehidupan Masyarakat, Cet. 27 (Bandung: Mizan, 2004).

Mochtar Kusumaatmadja. Makalah Seminar Tentang Temu Kenal Cita Hukum dan Penerapan Asas-asas Hukum Nasional Departemen Kehakiman RI, dalam Pemantapan Cita Hukum Dan Asas-asas Hukum Nasional di Masa Kini dan Masa Yang Akan Datang (Jakarta, 22-24 Mei 1995)..

Teungku Muhammad Hasbi ash-Shiddieqy. Tafsir al-Qur'anul Majid an-Nuur, Juz I, Cet. 2 (Semarang: Pustaka Rizki Utama, 2000).

Thabbârah, 'Afîf 'Abd al-Fattâh. Rûh al-Dîn al-Islâmî, Cet. 26 (Bayrût: Dâr al-'Ilm li alMalâyîn, 1985).

Zuhairi Misrawi. Al-Qur'an Kitab Toleransi: Tafsir Tematik Islam Rahmatan Lil Alamin (Jakarta: Gramedia Widiasarana Indonesia, 2010). 